\title{
Insect pests as food and feed
}

\author{
A. van Huis \\ Laboratory of Entomology, Wageningen University E Research, P.O. Box 16, 6700 AA Wageningen, the Netherlands; \\ editor-in-chief@insectsasfoodandfeed.com; arnold.vanhuis@wur.nl
}

(c) 2020 Wageningen Academic Publishers

OPEN ACCESS C) (9)(2) EDITORIAL

\section{Abstract}

When insects occur in large numbers, and these are often insect pests, people want to get rid of them. In countries where insects are already consumed, the idea of eating them is quickly formed. Harvesting them as food can be a strategy to replace other methods of control.

\section{Introduction}

Insect pests can be controlled mechanically when collected either for home consumption or for the market. In this case pest control and food procurement are combined. Sometimes the control obtained by consuming them may be limited, as is the case with certain locust species. For example, during an upsurge or a plague of the desert locust Schistocerca gregaria (Orthoptera: Acrididae), the swarms are often so large that the part of the locust population that can be harvested is not sufficient to contribute to population suppression. This is in addition to other logistical problems of finding and harvesting them (Van Huis et al., 2007).

A 'pest' is defined as any organism that causes annoyance or injury to human beings, human possessions, or human interests. Our definition of a crop pest is that it causes economic loss (Hill, 1997). Injury is the physical damage you can observe on a plant which may or may not lead to economic loss. An example of injury without yield loss is cutting a young maize plant to ground level while the yield remains the same or even increases (Hicks et al., 1977). This can simulate an armyworm attack (Brown and Mohamed, 1972). The shea caterpillar Cirina butyrospermi (Lepidoptera: Saturniidae) is collected and consumed, however it seems that the defoliation does not lead to yield loss of the shea nut tree the following year; on the contrary, the defoliation seems to increase the yield of maize growing underneath (Payne et al., 2019).

Below we will give some examples of pest insects from different orders being used either as food or feed. However, there is also an indirect way of controlling pests using edible insects. Frass of the black soldier fly Hermetia illucens (Diptera: Stratiomyidae) as soil amendment seems to control wireworms (Coleoptera: Elateridae) (Temple et al., 2013; Vickerson et al., 2017).

\section{Orthoptera}

\section{Locusts}

Locusts (Acrididae) are consumed when an upsurge or plague occurs. In the second century before Christ, Diodorus of Sicily already talks about 'acridophagi', the 'locust eaters' of Ethiopia (Bodenheimer, 1951: 41). The only risk associated with consuming locusts is poisoning since the insects may have been treated with pesticides (Saeed et al., 1993).

Other species besides the desert locust eaten in Africa are the red locust (Normadacris septemfasciata), the brown locust (Locustana pardalina), mentioned for example by Obopile and Seeletso (2013), and the (often reared) migratory locust (Locusta migratoria) (Mohamed, 2015). In Latin America the locust species Schistocerca cancellate, which has recently been causing upsurges (Medina et al., 2017), is also eaten (Loiácono et al., 2016).

In 1876 the U.S. Congress declared the Rocky Mountain locust (Melanoplus spretus) 'the single greatest impediment to the settlement of the country between Mississippi and the Rocky Mountains. Throughout the $19^{\text {th }}$ century, swarms of locusts swept across the American continent. In 1875, one swarm was estimated to be more than half a million $\mathrm{km}^{2}$. The outbreaks subsided in the 1890s and then vanished 
(last specimen found in 1902) and the species was declared formally extinct in 2014 (Hochkirch, 2014). The famous American entomologist C.V. Riley (1843-1895) headed a commission to fight the locust. About five pages of the first report of the commission were devoted to consuming the locust. This was mainly because Riley wanted to help people who were suffering from starvation (Lockwood, 2004: 116-117).

Between 1960 and 1970, the Bombay locust Nomadacris succincta was a major pest of corn and sorghum crops in Thailand (Chen et al., 1998). When aerial spraying with pesticides proved unsuccessful, a campaign was organised (1978 to 1981) to capture the locust for consumption. This was so successful that the locust is no longer a pest but rather one of the best known and most popular edible insects in Thailand (Hanboonsong, 2010).

\section{Grasshoppers}

In the Sahelian region of Africa many grasshopper species are eaten, most of which are crop pests (Van Huis, 2003). Jago et al. (1993) showed that the investment in pesticides to control grasshoppers in millet does not pay off. In fact the sale of grasshoppers from the millet raised more revenue for the farmers than selling the millet (Van Huis, 2016). Many articles have been written about the pest status and control of the variegated grasshopper Zonocerus variegatus (Pyrgomorphidae) in West Africa. However, few publications deal with its role in the human diet. The insect is very much appreciated because of its taste and nutritional value (Kekeunou et al., 2020).

In most of Asia, rice field grasshoppers of the genus Oxya spp. (Acrididae) are traditional food. However, increased pesticide use in the final quarter of the twentieth century reduced its abundance (Payne, 2015).

The grasshopper Sphenarium purpurascens (Pyrgomorphidae) is a pest of corn, bean, pumpkin, and alfalfa in Mexico, but is also a popular food. Cerritos Flores et al. (2015) proposed changing the practice of using pesticides to harvest them mechanically for human consumption.

\section{Coleoptera}

The lesser mealworm, Alphitobius diaperinus (Coleoptera: Tenebrionidae), is a common insect pest in commercial poultry farms. It appears in large numbers in poultry litter and manure, and even eats sick and weakened or dead chickens. The lesser mealworm is a source and vector of several pathogens such as bacteria, viruses, fungi, protozoa, and platyhelminths that cause serious poultry and human diseases (De Las Casas et al., 1968; McAllister et al., 1996;
Poole and Crippen, 2009; Szczepanik et al., 2019; Watson et al., 2000). The lesser mealworm is now an insect that is commercially reared as food on side-streams of the agrifood sector (Gianotten et al., 2020; Rumbos et al., 2018).

An example of an insect that people are starting to consider eating and that occurs in huge numbers is the cockchafer Melolontha sp. (Scarabaeidae). This pest insect was very abundant in Europe until pesticides were used. The larvae eat the roots of plants and develop in the earth for three to four years, which is why they appear in a cycle of every three or four years. Bodenheimer (1951: 66) mentions that in years of famine, such as in 1688 in Ireland, people would eat them. Cockchafer soup is a European dish made from the cockchafer insect. It was a delicacy in Germany and France until the mid-1900s. Also in Luxembourg they were made into a soup, in particular during the plagues in 1868 , 1880 and in 1896, when children were paid to collect them (Massard, 2007). In the Philippines the grub Leucopholis irrorata (Scarabaeidae) is a serious pest in maize and rice (Litsinger et al., 1983), but is at the same time considered a delicacy (grubs grilled over charcoal, deep-fried, spicy adobo and sautéed with vegetables) (Adalla and Cervancia, 2010). In India another white grub Lepidiota mansueta (Scarabaeidae) is a serious pest of potato, sugarcane, Colocasia, and green gram (Bhattacharyya et al., 2015). Majuli, an island on the Brahmaputra River in Assam, one of the largest freshwater islands in the world, has been severely infested by the beetle. Farmers now make dishes from the beetle: for example, roasted beetle fried with tomato, plain roasted beetle and beetle curry (Borah, 2016).

There are several other coleopteran pests which have become a popular food all over the world, such as the palm weevil Rhynchophorus spp. (Curculionidae) and rhinoceros beetles Oryctes spp. (Scarabaeidae) in palms; their consumption is a pest management strategy (DeFoliart, 1993).

\section{Hymenoptera}

In 2019, a giant hornet was spotted in Washington State in the USA, and since then alarming newspaper articles have talked about the 'murder hornet' (it may kill bees, but rarely humans). The wasps come from Japan, where they are called 'hebo' (Vespula spp.) (Vespidae). It is a popular food in some parts of the country (Nonaka and Yanagihara, 2019).

However, there is another way of turning insect pests into food. This is accomplished by the weaver ant Oecophylla spp. (Formicidae), which is used as a biological control agent (predator) for insect pests in orchards (Van Mele, 2008). The weaver ant is a popular food in most of southeast Asia (Offenberg and Wiwatwitaya, 2009). 


\section{Lepidoptera}

One of the major teak pests around the world is Hyblaea puera (Hyblaeidae), which defoliates the trees (Tripathy et al., 2018). However, the cocoons are considered a delicacy in Java, Indonesia (Lukiwati, 2010).

Worldwide, foresters have looked at insect pests as wood pests to be suppressed or controlled (Schabel, 2010). However, many insect pests in forests are edible, such as the caterpillars in central Africa (Malaisse, 1997: 199-218).

\section{Diptera}

In an editorial of the first issue of this journal this year, Tomberlin and Van Huis (2020) indicated that in the past the black soldier fly was considered a pest, as it could produce myiasis in humans and pets. Now it is considered a promising species in the biotransformation of organic waste and as feed for pets, fish, poultry, and pigs. The same is true for the house fly Musca domestica (Muscidae), which is considered a pest while the maggots can also be used as feed (Van Huis et al., 2020).

An opportunity exists when pest insects are artificially available in large numbers. This is the case for the Mediterranean fruit fly Ceratitis capitata (Tephritidae), which is mass-reared in controlled facilities and whose sterile males are released as a control method (Gavriel et al., 2010). Such facilities are present in Israel, prompting one company there to make protein and oil out of the larvae; the powder is used as an additive in baked goods and energy bars.

\section{Conclusion}

When insects occur in large numbers (such as locusts) people are more inclined to use them as food, even in the western world as mentioned above in the case of the Rocky Mountain locust and cockchafers. In addition, when they are available by rearing them for other purposes such as the sterile insect technique, they may also be considered as food or feed (e.g. the Mediterranean fruit fly). Control of pests by pesticides often causes resurgence or secondary pest outbreaks (DeBach, 1964), for example in rice agroecosystems, as they are controlled by a huge reservoir of natural enemies (Settle et al., 1996). By refraining from using pesticides, there are opportunities to use insect pests as food, such as the Oxya spp. grasshoppers in Asia. Several fly species were considered pests in the past, but are now used as food or feed.

\section{References}

Adalla, C.B. and Cervancia, C.R., 2010. Philippine edible insects: a new opportunity to bridge the protein gap of resource-poor families and to manage pests. In: Durst, P.B., Johnson, D.V. Leslie, R.N. and Shono, K. (eds.) Forest insects as food: humans bite back. Food and Agriculture Organization of the United Nations. Regional Office for Asia and the Pacific, Bangkok, Thailand, pp. 151-160. Available at: http://www.fao.org/3/a-i1380e.pdf.

Bhattacharyya, B., Pujari, D., Bhuyan, U., Handique, G., Baruah, A.A.L.H., Dutta, S.K. and Tanaka, S., 2015. Seasonal life cycle and biology of Lepidiota mansueta (Coleoptera: Scarabaeidae): a serious root-feeding pest in India. Applied Entomology and Zoology 50: 435-442. https://doi.org/10.1007/s13355-015-0349-4

Bodenheimer, F.S., 1951. Insects as human food; a chapter of the ecology of man. Dr. W. Junk, Publishers, The Hague, the Netherlands, 352 pp.

Borah, A., 2016. The Majuli beetle turns from pest to delicacy. India Climate Dialogue, New Delhi, India. Available at: https://tinyurl. com/yajjmphg

Brown, E.S. and Mohamed, A.K.A., 1972. The relation between simulated armyworm damage and crop-loss in maize and sorghum. East African Agricultural and Forestry Journal 37: 237-257. https:// doi.org/10.1080/00128325.1972.11662534

Cerritos Flores, R., Ponce-Reyes, R. and Rojas-García, F., 2015. Exploiting a pest insect species Sphenarium purpurascens for human consumption: ecological, social, and economic repercussions. Journal of Insects as Food and Feed 1: 75-84. https://doi.org/10.3920/ JIFF2014.0013

Chen, P.P., Wongsiri, S., Jamyanya, T., Rinderer, T.E., Vongsamanode, S., Matsuka, M., Sylvester, H.A. and Oldroyd, B.P., 1998. Honey bees and other edible insects used as human food in Thailand. American Entomologist 44: 24-29. https://doi.org/10.1093/ae/44.1.24

De Las Casas, E., Pomeroy, B.S. and Harein, P.K., 1968. Infection and quantitative recovery of Salmonella typhimurium and Escherichia coli from within the lesser mealworm, Alphitobius diaperinus (Panzer). Poultry Science 47: 1871-1875. https://doi.org/10.3382/ ps.0471871

DeBach, P., 1964. Biological control of insect pests and weeds. Chapman \& Hall, London, UK, 844 pp.

DeFoliart, G.R., 1993. Hypothesizing about palm weevil and palm rhinoceros beetle larvae as traditional cuisine, tropical waste recycling, and pest and disease control on coconut and other palms - can they be integrated? Principes 37: 42-47.

Gavriel, S., Gazit, Y. and Yuval, B., 2010. Effect of diet on survival, in the laboratory and the field, of sterile male Mediterranean fruit flies. Entomologia Experimentalis et Applicata 135: 96-104. https://doi. org/10.1111/j.1570-7458.2010.00972.x

Gianotten, N., Soetemans, L. and Bastiaens, L., 2020. Agri-food sidestream inclusions in the diet of Alphitobius diaperinus Part 1: Impact on larvae growth performance parameters. Insects 11: 79. https:// doi.org/10.3390/insects11020079 
Hanboonsong, Y., 2010. Edible insects and associated food habits in Thailand. In: Durst, P.B., Johnson, D.V. Leslie, R.N. and Shono, K. (eds.) Forest insects as food: humans bite back. Food and Agriculture Organization of the United Nations. Regional Office for Asia and the Pacific, Bangkok, Thailand, pp. 173-182. Available at: http:// www.fao.org/3/a-i1380e.pdf.

Hicks, D.R., Nelson, W.W. and Ford, J.H., 1977. Defoliation effects on corn hybrids adapted to the northern corn belt. Agronomy Journal 69: 387-390. https://doi.org/10.2134/agronj1977.000219 $62006900030014 x$

Hill, D.S., 1997. Pest definitions. In: D.S. Hill (ed.) The economic importance of insects. Springer, Dordrecht, the Netherlands, pp. 51-63. https://doi.org/10.1007/978-94-011-5348-5_3

Hochkirch, A., 2014. Melanoplus spretus (errata version published in 2017). The IUCN red list of threatened species 2014: e.T51269349A111451167. https://doi.org/10.2305/IUCN.UK.2014-1. RLTS.T51269349A55309428.en

Jago, N.D., Kremer, A.R. and West, C., 1993. Pesticides on millet in Mali. NRI Bulletin 50. Natural Resources Institute, Chatham, UK, 45 pp. Available at: https://gala.gre.ac.uk/id/eprint/11080/

Kekeunou, S., Laïda, P.S., Achu-Loh, M.B., Tchouamou, C.L.D., SimoGuiadem, L., Pieme, C.A., Ngameni, B. and Tamesse, J.L., 2020. Ethnic heterogeneity of knowledge on Zonocerus variegatus and reasons for consumption and non-consumption in the south part of Cameroon. Journal of Insects as Food and Feed 6: 273-283. https:// doi.org/10.3920/JIFF2019.0035

Litsinger, J.A., Apostol, R.F. and Obusan, M.B., 1983. White Grub, Leucopholis irrorata (Coleoptera: Scarabaeidae): pest status, population dynamics, and chemical control in a rice-maize cropping pattern in the Philippines. Journal of Economic Entomology 76: 1133-1138. https://doi.org/10.1093/jee/76.5.1133

Lockwood, J.A., 2004. Locust: the devastating rise and disappearance of the insect that shaped the American frontier. Basic Books, New York, NY, USA.

Loiácono, M.S., Margaría, C., Giovannetti, M.A. and Silva, S., 2016. Anthropo-entomophagy in Guaycurú linguistic groups from Argentina: past and present. Journal of Insects as Food and Feed 2: 15-26. https://doi.org/10.3920/JIFF2015.0075

Lukiwati, D.R., 2010. Teak caterpillars and other edible insects in Java. In: Durst, P.B., Johnson, D.V. Leslie, R.N. and Shono, K. (eds.) Forest insects as food: humans bite back. Food and Agriculture Organization of the United Nations. Regional Office for Asia and the Pacific, Bangkok, Thailand, pp. 99-103. Available at: http:// www.fao.org/3/a-i1380e.pdf.

Malaisse, 1997. Se nourir en forêt claire Africaine: approche ecologique et nutritionnelle. Les Presses Agronomiques de Gembloux, Gembloux, Belgium.

Massard, J.A., 2007. Maikäfer in Luxemburg: Historisches und Kurioses. Lëtzebuerger Journal 60: 26-27. http://massard.info/ pdf/maikaefer.pdf

McAllister, J.C., Steelman, C.D., Skeeles, J.K., Newberry, L.A. and Gbur, E.E., 1996. Reservoir competence of Alphitobius diaperinus (Coleoptera: Tenebrionidae) for Escherichia coli (Eubacteriales: Enterobacteriaceae). Journal of Medical Entomology 33: 983-987. https://doi.org/10.1093/jmedent/33.6.983
Medina, H., Cease, A. and Trumper, E., 2017. The resurgence of the South American locust (Schistocerca cancellata). Metaleptea 37: 17-21.

Mohamed, E.H.A., 2015. Determination of nutritive value of the edible migratory locust Locusta migratoria, Linnaeus, 1758 (Orthoptera: Acrididae). International Journal of Advances in Pharmacy, Biology and Chemistry 4: 144-148.

Nonaka, K. and Yanagihara, H., 2019. Reviving the consumption of insects in Japan: a promising case of hebo (Vespula spp., wasps) by high school club activities. Journal of Insects as Food and Feed 6: 45-50. https://doi.org/10.3920/JIFF2019.0005

Obopile, M. and Seeletso, M., 2013. Eat or not eat: an analysis of the status of entomophagy in Botswana. Food Security 5: 817-824. https://doi.org/10.1007/a12571-013-0310-8

Offenberg, J. and Wiwatwitaya, D., 2009. Weaver ants convert pest insects into food - prospects for the rural poor. In: Proceedings of the Conference on International Research on Food Security, Natural Resource Management and Rural Development, Tropentag 2009, University of Hamburg, Germany, October 6-8, 2009. Available at: https://tinyurl.com/y72ybruz

Payne, C., Badolo, A., Sagnon, B., Cox, S., Pearson, S., Sanon, A., Bationo, F. and Balmford, A., 2020. Effects of defoliation by the edible caterpillar 'chitoumou' (Cirina butyrospermi) on harvests of shea (Vitellaria paradoxa) and growth of maize (Zea mays). Agroforestry Systems 94: 231-240. https://doi.org/10.1007/s10457-019-00385-5

Payne, C.L.R., 2015. Wild harvesting declines as pesticides and imports rise: the collection and consumption of insects in contemporary rural Japan. Journal of Insects as Food and Feed 1: 57-65. https:// doi.org/10.3920/JIFF2014.0004

Poole, T. and Crippen, T., 2009. Conjugative plasmid transfer between Salmonella enterica Newport and Escherichia coli within the gastrointestinal tract of the lesser mealworm beetle, Alphitobius diaperinus (Coleoptera: Tenebrionidae). Poultry Science 88: 15531558. https://doi.org/10.3382/ps.2008-00553

Rumbos, C.I., Karapanagiotidis, I.T., Mente, E. and Athanassiou, C.G., 2018. The lesser mealworm Alphitobius diaperinus: a noxious pest or a promising nutrient source? Reviews in Aquaculture 11: 14181437. https://doi.org/10.1111/raq.12300

Saeed, T., Dagga, F.A. and Saraf, M., 1993. Analysis of residual pesticides present in edible locusts captured in Kuwait. Arab Gulf Journal of Scientific Research 11: 1-5.

Schabel, H.G., 2010. Forest insects as food: a global review. In: Durst, P.B., Johnson, D.V. Leslie, R.N. and Shono, K. (eds.) Forest insects as food: humans bite back. Food and Agriculture Organization of the United Nations. Regional Office for Asia and the Pacific, Bangkok, Thailand, pp. 37-64. Available at: http://www.fao.org/3/a-i1380e.pdf. Settle, W.H., Ariawan, E.T., Astuti, W., Cahyana, A.L., Hakim, D., Hindayana, A.S., Lestari and Pajamingsih, 1996. Managing tropical rice pests through conservation of generalist natural enemies and alternative prey. Ecology 77: 1975-1988. https://doi. org/10.2307/2265694

Szczepanik, M., Raszkowska-Kaczor, A., Olkiewicz, D., Bajer, D. and Bajer, K., 2020. Use of starch granules enriched with carvacrol for the lesser mealworm, Alphitobius diaperinus control in chicken house: effects on insects and poultry. The Journal of Poultry Science 57: 168-174. https://doi.org/10.2141/jpsa.0190068 
Temple, W.D., Radley, R., Baker-French, J. and Richardson, F., 2013. Use of Enterra natural fertilizer (black soldier fly larvae digestate) as a soil amendment. Enterra Feed Corporation, Langley City, Canada.

Tomberlin, J.K. and Van Huis, A., 2020. Black soldier fly from pest to 'crown jewel' of the insects as feed industry: an historical perspective. Journal of Insects as Food and Feed 6: 1-4. https://doi.org/10.3920/ JIFF2020.0003

Tripathy, M.K., Rout, M. and Tripathy, A., 2018. Population dynamics of teak defoliator, Hyblaea puera Cramer at coastal Odisha, India. Journal of Entomology and Zoology Studies 6: 2378-2387.

Van Huis, A., 2003. Insects as food in sub-Saharan Africa. Insect Science and its Application. 23: 163-185.

Van Huis, A., 2016. Préface. In: Le Gall, Ph. and Motte-Florac, E. (eds.) Savoureux insectes: d'aliment traditionelles à l'innovation gastronomique, pp. 7-10. Peeters, Leuven, Belgium.

Van Huis, A., Cressman, K. and Magor, J.I., 2007. Preventing desert locust plagues: optimizing management interventions: mini review. Entomologia Experimentalis et Applicata 122: 191-214. https://doi. org/10.1111/j.1570-7458.2006.00517.x
Van Huis, A., Oonincx, D.G.A.B., Rojo, S. and Tomberlin, J.K., 2020. Insects as feed: house fly or black soldier fly? Journal of Insects as Food and Feed 6: 221-229. https://doi.org/10.3920/JIFF2020.x003

Van Mele, P., 2008. A historical review of research on the weaver ant Oecophylla in biological control. Agricultural and Forest Entomology 10: 13-22. https://doi.org/10.1111/j.1461-9563.2007.00350.x

Vickerson, A., Radley, R., Marchant, B., Kaulfuss, O. and Kabaluk, T., 2017. Hermetia illucens frass production and use in plant nutrition and pest management. United States Patent Application: 0190343148.

Watson, D.W., Guy, J.S. and Stringham, S.H., 2000. Limited transmission of turkey coronavirus in young turkeys by adult Alphitobius diaperinus (Coleoptera: Tenebrionidae). Journal of Medical Entomology 37: 480-483. https://doi.org/10.1093/ jmedent/37.3.480 
